\title{
Fabrication of Porous Alumina Sintered Bodies by a Gelate-Freezing Method
}

\author{
Masayuki NAKATA, Kimiaki TANIHATA, ${ }^{*}$ Shunro YAMAGUCHI* and Katsuaki SUGANUMA* \\ Dept. of Adaptive Machine Systems, Graduate School of Engineering, Osaka University, 8-1, Mihogaoka, Ibaraki-shi, Osaka 567-0047 \\ ${ }^{*}$ Institute of Scientific and Industrial Research, Osaka University, 8-1, Mihogaoka, Ibaraki-shi, Osaka 567-0047
}

\author{
ゲル化凍結法による多孔性アルミナ焼結体の作製 \\ 中田昌幸 ·谷畑公昭* · 山口俊郎* ·菅沼克昭* \\ 大阪大学大学院工学研究科知能機能創成工学専攻, 567-0047 大阪府茨木市美穗ヶ丘 8-1 \\ *大阪大学産業科学研究所, 567-0047 大阪府茨木市美穂ヶ丘 8-1
}

\begin{abstract}
Porous alumina sintered bodies were fabricated by a new gelate-freezing method. The fabricated porous alumina sintered bodies possess highly continuous open pores, and a wide range of pore size (20-200 $\mu \mathrm{m})$ and porosity $(30-70 \%)$. Inside the alumina only a few micro voids were observed. Pore size and porosity were able to be controlled by the alumina and water content in the slurry, and by the cooling temperature and direction.
\end{abstract}

[Received March 22, 2005; Accepted August 19, 2005]

Key-words : Porous ceramics, Water solved polymer, Gel-casting method, Freeze-dry method

\section{Introduction}

Porous ceramics are important materials for a variety of applications such as molten metal filters, ${ }^{1)}$ light materials, refractory tiles, catalyst carrier, ${ }^{2)}$ sensors $^{3)}$ and artificial bones. For fabrication of these materials the gel-casting method $^{4)-6)}$ has been widely used. The porosity of the fabricated ceramics is easily controlled; however, pore sizes are limited. Recently, there has been much interest in ceramics filters, which require high porosity, continuous open pores, and control of the pore size. For fabrication of ceramics filters, the freeze-dry method ${ }^{7)-9)}$ have been widely used. Generally, the porous ceramics obtained have had high porosity and highly oriented pores, though vacuum dehydration has been needed in the drying process.

In this paper, to fabricate porous alumina sintered bodies with high porosity, continuous open pores, and a wide range of pore sizes, we developed a new gelate-freezing method. We achieved fabrication of porous alumina sintered bodies with the desired characteristics. Moreover, by using a fine alumina powder, porous alumina with a dense alumina part was fabricated. Pore size and porosity were able to be controlled by the alumina and water content in the slurry. Moreover, the structure of the porous alumina sintered bodies was controlled by the cooling temperature and direction.

\section{Experimental procedure}

2.1 Fabrication of porous alumina sintered bodies by the gelate-freezing method

A flow chart of gelate-freezing method is shown in Fig. 1. Fine-grained alumina powder (Sumitomo Chem., Co., Ltd., AKP 30: grain size $0.3 \mu \mathrm{m}$ ), water soluble polymer solution (Aldrich: polyethylene-imine 3-15 mass\% solution), and gelling agent (Aldrich: di-glycerol-glycygel-ether) were used. Alumina powder and polymer solution were mixed for $30 \mathrm{~s}$ in a mixing vessel $(\phi 31 \mathrm{~mm})$, and then de-aired for $30 \mathrm{~s}$ by a stirrer (KEYENCE Co., Ltd., HM-500). The gelling agent was added to the mixed slurry at a rate of $1.21 \mathrm{~g}$ agent to $10 \mathrm{~g}$ slurry. After being mixed for $30 \mathrm{~s}$ and de-aired for $30 \mathrm{~s}$ by the stirring equipment, the slurry was kept for $0.5-3 \mathrm{~h}$, depending on slurry concentration, in air for completion of the gelling.

The resulting gel in the vessel was frozen by one of the fol-

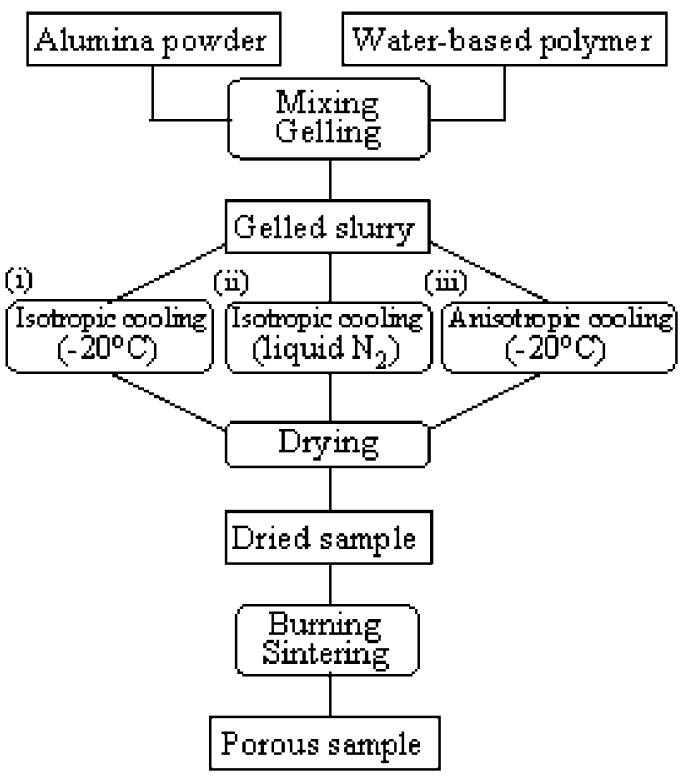

Fig. 1. Flow chart of the gelate-freezing method.

lowing three methods, (i) isotropic cooling at $-20^{\circ} \mathrm{C}$ for $3 \mathrm{~h}$ in a freezer, (ii) isotropic cooling with liquid nitrogen for $1 \mathrm{~h}$ in a Dewar vessel after isotropic cooling at $-20^{\circ} \mathrm{C}$, and (iii) anisotropic cooling from the bottom of the vessel at $-20^{\circ} \mathrm{C}$ for $3 \mathrm{~h}$. A schematic illustration of the anisotropic cooling is shown in Fig. 2. The vessel was composed of two parts; the bottom part made of an aluminum plate, and the side part of resin. The alumina gel was cooled from the bottom of the vessel.

After being taken out of the vessel, the resulting frozen gel was set in a drying device in the hot air dryer. The drying equipment is shown in Fig. 3. Samples were thawed and dried at $30-35^{\circ} \mathrm{C}$. Removal of water in the sample was monitored by weighing the sample. After $90 \%$ of the water was removed, the sample was kept at $600^{\circ} \mathrm{C}$ for $1 \mathrm{~h}$ in an electric furnace. The resulting sample was sintered at $1500^{\circ} \mathrm{C}$ for $3 \mathrm{~h}$. 


\subsection{Characterization}

Relative densities were determined from the weight and dimensions of the sintered bodies, and porosity was calculated from the relative density. The microstructure of the specimen was observed by an optical microscope and a scanning electron microscope (SEM). The pore size distributions of the sintered bodies were measured by analysis of the image picture.

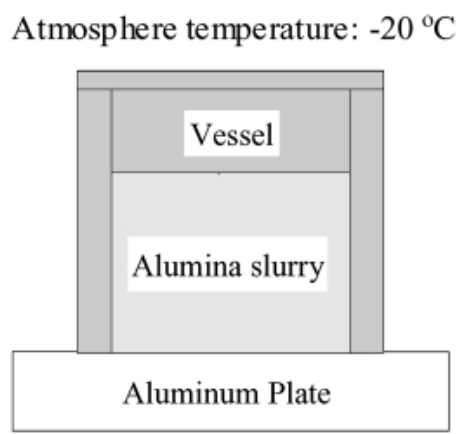

Fig. 2. Schematic illustration of the anisotropic cooling apparatus.

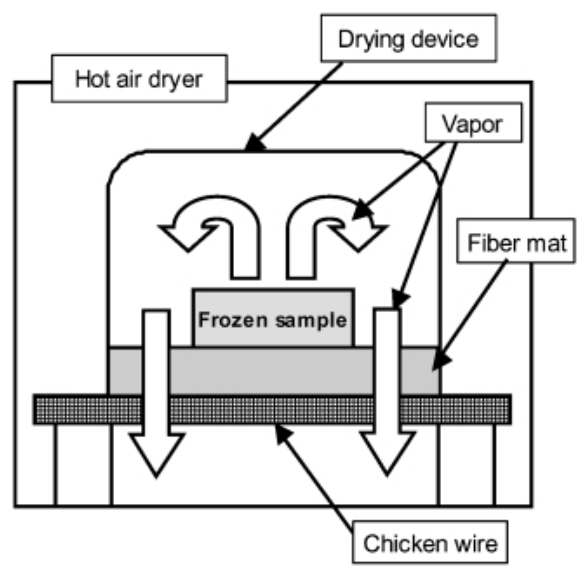

Fig. 3. Schematic illustration of the drying equipment.

\section{Results}

3.1 Porosity of the porous alumina sintered bodies

Fabrication conditions and porosity of the obtained porous alumina sintered bodies are listed in Table 1. The porosity at under fabrication condition was determined from the average of four samples. By decreasing the content of alumina, the porosity increased from $30 \%$ to $70 \%$. At the same volume ratio of alumina, the porosity of sintered bodies depended on the water content in the polymer.

3.2 Pore structure of the porous alumina sintered bodies by isotropic cooling

Optical microscopic photographs of the porous alumina sintered bodies fabricated by isotropic cooling are shown in Fig. 4. The pores of the alumina sintered bodies were filled with polystyrene that corresponded to the dark parts. In each case, orientated pore structures were not observed. Large pores with a high aspect ratio (major axis about $200 \mu \mathrm{m}$, and minor axis about $30 \mu \mathrm{m}$ ) were observed in Fig. 4(a). Compared with Figs. 4(a) and (b) showed a branched structure. The pore size distributions of the porous alumina sintered bodies are shown in Fig. 5. The mean pore size was calculated from the average of the major and miner axes of the pores. The mean pore size of entries 4, 6 and 8 were about 80,60 , and $140 \mu \mathrm{m}$, respectively. The aspect ratios of the porous alumina sintered bodies are shown in Fig. 6. Compared with entries 4 and 6 , samples that were prepared under lower water content showed a broad distribution of the aspect ratio and branched structures. Compared with the samples of entries 4 and 8 , the distribution and peak values of the aspect ratio decreased with increasing alumina content in the slurry.

Figure 7 shows the alumina texture of entry 8. A few microscopic closed pores of $1 \mu \mathrm{m}$ were found in the alumina texture; while a dense alumina structure was observed.

We examined the cooling temperature effect in entry 8, which showed a favorable aspect ratio of the components for the fabrication of porous alumina sintered bodies with fairly high porosity. An optical microscopic photograph of a porous alumina sintered body with $70 \%$ porosity, which was fabricated with cooling by liquid nitrogen (entry 9), is shown in Fig. 8. Compared with entry 8 shown in Fig. 4(c), the pore structure significantly differs; the pore and alumina texture sizes of the sample frozen in liquid nitrogen were larger than the sample frozen at $-20^{\circ} \mathrm{C}$.

Table 1. Porosity of Porous Alumina Sintered Bodies Fabricated by Isotropic Cooling at $-20^{\circ} \mathrm{C}$, by Isotropic Cooling at $-20^{\circ} \mathrm{C}$ and by Liquid Nitrogen and Anisotropic Cooling at $-20^{\circ} \mathrm{C}$

\begin{tabular}{|c|c|c|c|c|}
\hline Entry No. & $\begin{array}{l}\text { Alumina concent }(\mathrm{vol} \%) \\
\text { [Alumina }(\mathrm{g})]\end{array}$ & $\begin{array}{c}\text { Polymer concent }(\mathrm{wt} \%) \\
{[\text { Poly mer, Water }(\mathrm{g})]}\end{array}$ & $\begin{array}{l}\text { Porosity } \\
\text { (\%) }\end{array}$ & $\begin{array}{l}\text { Cooling } \\
\text { conditions }\end{array}$ \\
\hline 1 & \multirow[t]{2}{*}{$40[8.0]$} & $7[0.21,2.79]$ & $31 \pm 1.5$ & \multirow[t]{8}{*}{ isotropic $\left(-20^{\circ} \mathrm{C}\right)$} \\
\hline 2 & & $5[0.15,2.85]$ & $41 \pm 0.8$ & \\
\hline 3 & \multirow[t]{4}{*}{$33[8.0]$} & $15[0.60,3.40]$ & $37 \pm 1.5$ & \\
\hline 4 & & $10[0.40,3.60]$ & $44 \pm 1.5$ & \\
\hline 5 & & $7[0.28,3.72]$ & $45 \pm 1.0$ & \\
\hline 6 & & $3[0.12,3.88]$ & $49 \pm 2.6$ & \\
\hline 7 & \multirow[t]{2}{*}{$20[8.0]$} & $7[0.56,7.44]$ & $64 \pm 0.7$ & \\
\hline 8 & & $5[0.40,7.60]$ & $71 \pm 2.9$ & \\
\hline 9 & $20[8.0]$ & $5[0.40,7.60]$ & $69 \pm 0.2$ & liquid $\mathrm{N}_{2}\left(-196^{\circ} \mathrm{C}\right)$ \\
\hline 10 & $20[8.0]$ & $5[0.40,7.60]$ & $70 \pm 0.5$ & anisotropic $\left(-20^{\circ} \mathrm{C}\right)$ \\
\hline
\end{tabular}



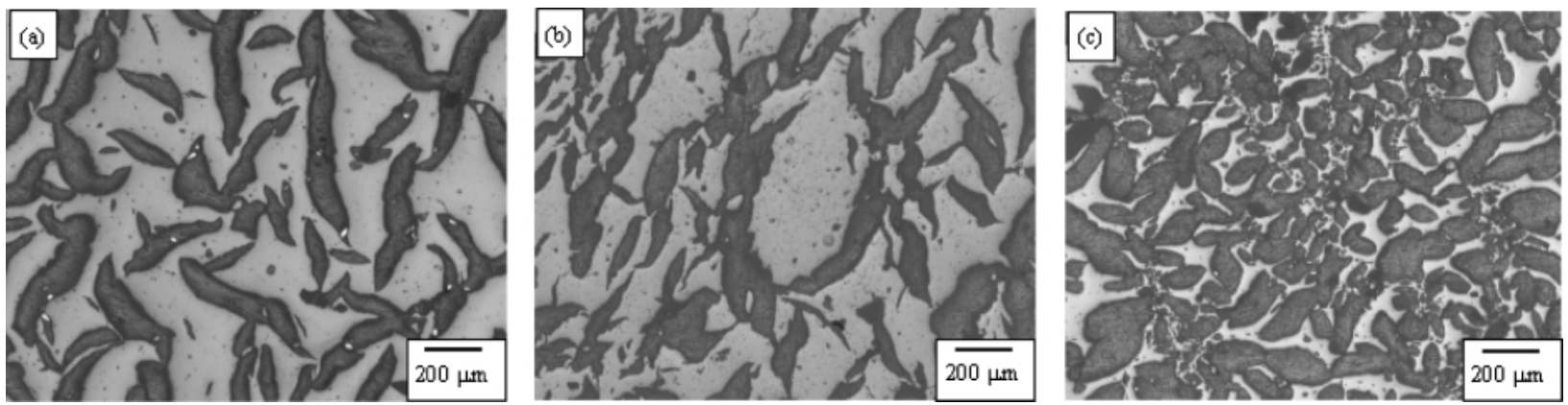

Fig. 4. Optical microscopic photographs of the porous alumina sintered bodies fabricated by isotropic cooling at $-20^{\circ} \mathrm{C}$; (a) entry 4 (porosity $44 \%, \mathrm{Al}_{2} \mathrm{O}_{3}$ concent $33 \mathrm{vol} \%$, polymer concent 10 mass $\%$ ), (b) entry 6 (porosity $55 \%, \mathrm{Al}_{2} \mathrm{O}_{3}$ concent 33 vol $\%$, polymer concent 3 mass $\%$ ) and (c) entry 8 (porosity $72 \%, \mathrm{Al}_{2} \mathrm{O}_{3}$ concent $20 \mathrm{vol} \%$, polymer concent 5 mass $\%$ ).

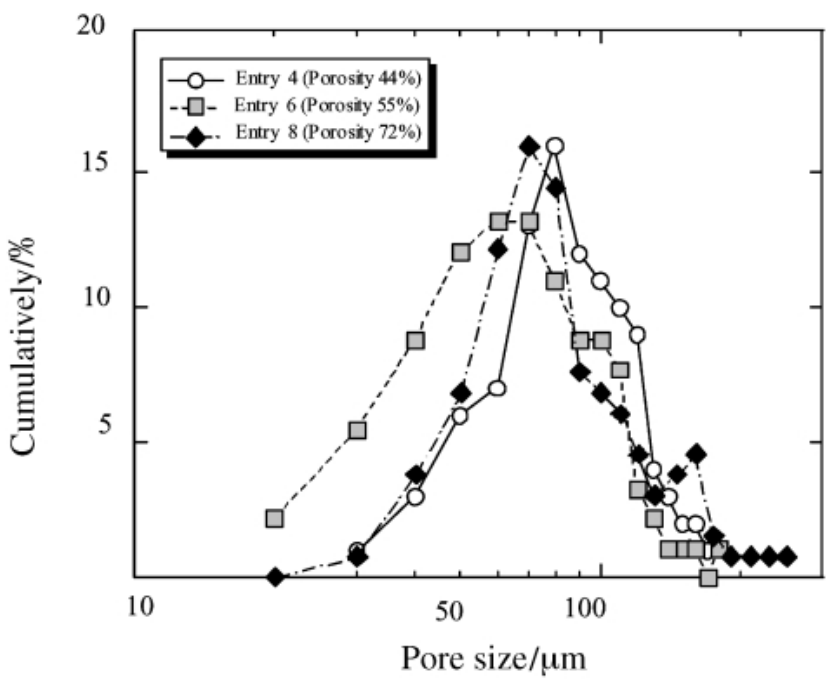

Fig. 5. Pore size distribution of porous alumina bodies; entry 4 (porosity $44 \%, \mathrm{Al}_{2} \mathrm{O}_{3}$ concent $33 \mathrm{vol} \%$, polymer concent 10 mass $\%$ ), entry 6 (porosity $55 \%, \mathrm{Al}_{2} \mathrm{O}_{3}$ concent $33 \mathrm{vol} \%$, polymer concent 3 mass $\%$ ) and entry 8 (porosity $72 \%, \mathrm{Al}_{2} \mathrm{O}_{3}$ concent 20 vol $\%$, polymer concent 5 mass \%).

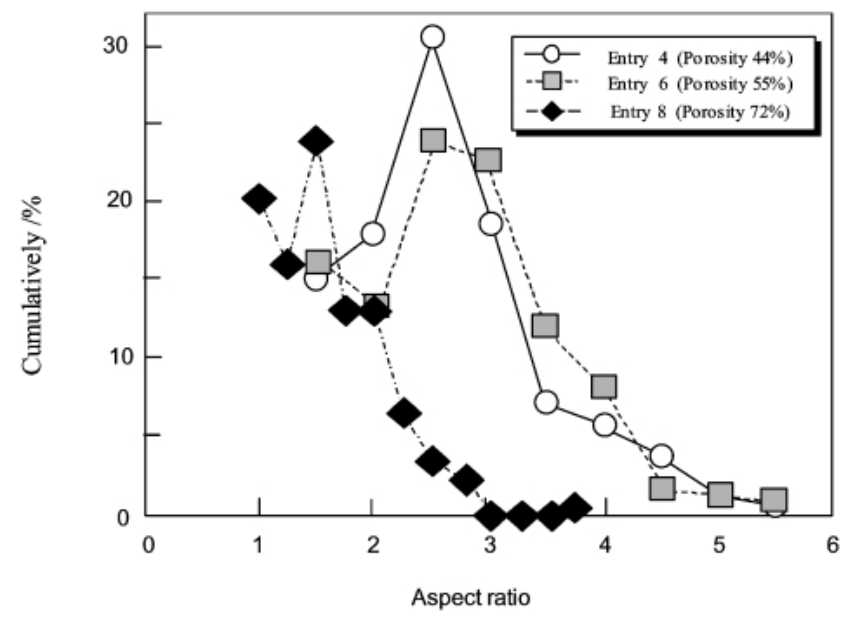

Fig. 6. Aspect ratios of porous alumina sintered bodies; entry 4 (porosity $44 \%, \mathrm{Al}_{2} \mathrm{O}_{3}$ concent $33 \mathrm{vol} \%$, polymer concent 10 mass $\%$ ), entry 6 (porosity $55 \%, \mathrm{Al}_{2} \mathrm{O}_{3}$ concent $33 \mathrm{vol} \%$, polymer concent 3 mass $\%$ ) and entry 8 (porosity $72 \%, \mathrm{Al}_{2} \mathrm{O}_{3}$ concent 20 vol $\%$, polymer concent 5 mass\%).

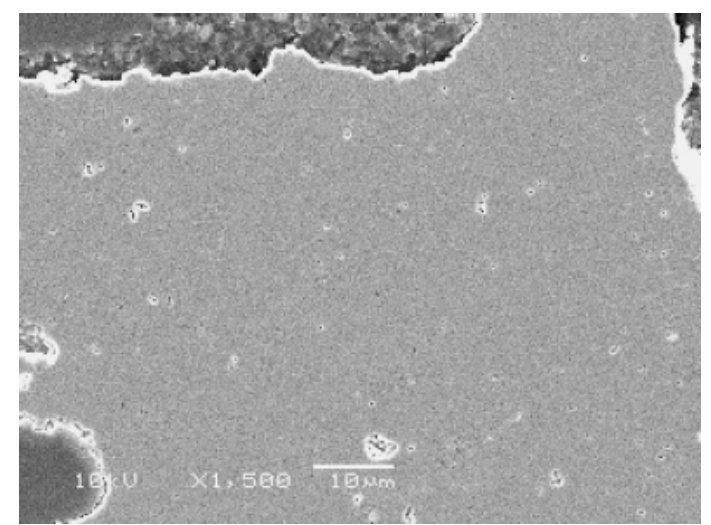

Fig. 7. SEM micrograph of porous alumina sintered bodies fabricated by isotropic cooling at $-20^{\circ} \mathrm{C}$; entry 8 , porosity $72 \%\left(\mathrm{Al}_{2} \mathrm{O}_{3}\right.$ concent 20 vol $\%$, polymer concent 5 mass $\%$ ).

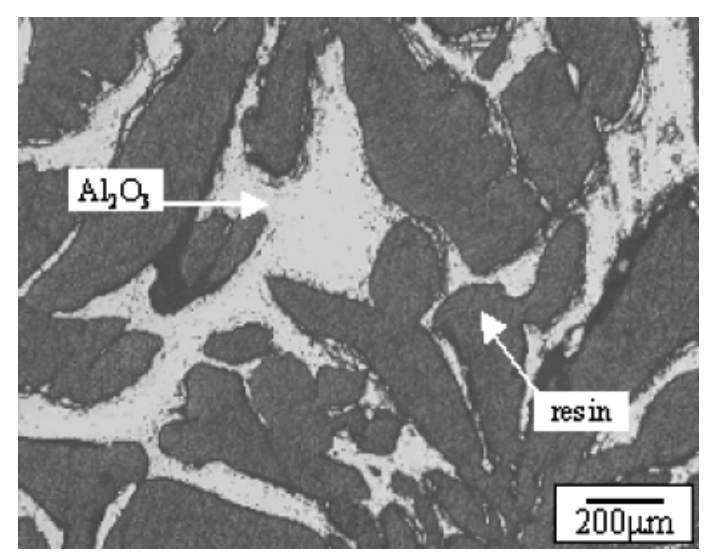

Fig. 8. Optical microscopic photograph of aluminum porous sintered bodies fabricated by isotropic cooling at $-20^{\circ} \mathrm{C}$ and by successive cooling with liquid nitrogen; entry 9 , porosity $72 \%\left(\mathrm{Al}_{2} \mathrm{O}_{3}\right.$ concent $20 \mathrm{vol} \%$, polymer concent 5 mass $\%$ ).

3.3 Pore structure of the porous alumina sintered bodies by anisotropic cooling

Optical microscopic photographs of cross sections parallel and perpendicular to the cooling direction of the porous alumina sintered body of entry 10 are shown in Figs. 9 (a) and (b), respectively. These porous alumina sintered bodies were fabricated under similar conditions to entry 8, except for 

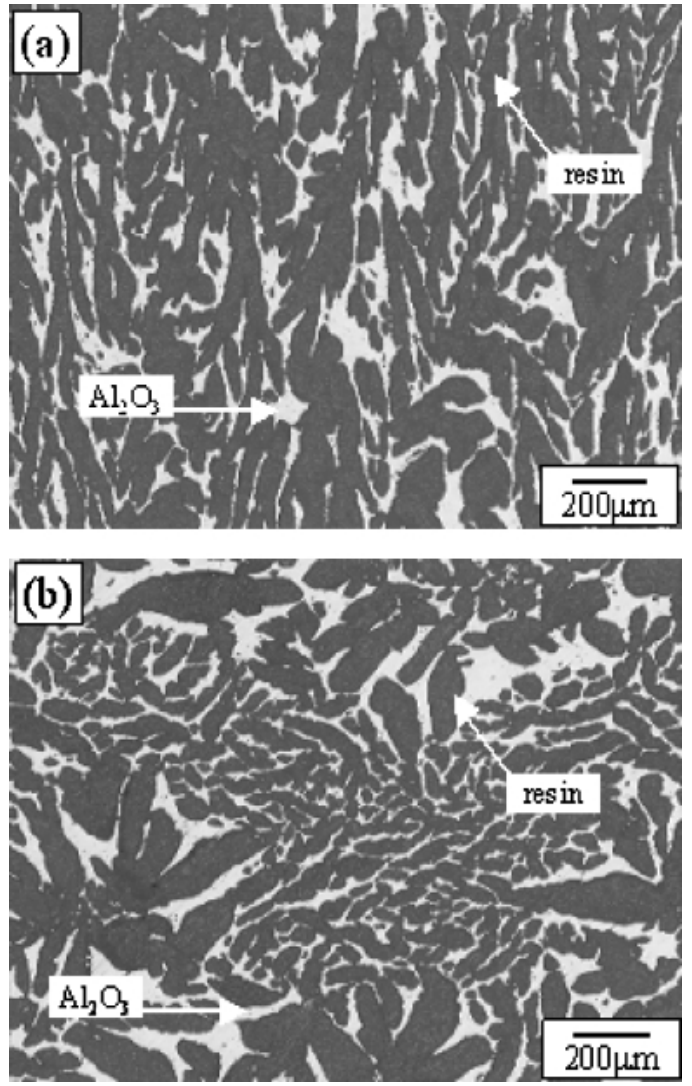

Fig. 9. Optical microscopic photographs of aluminum porous sintered bodies fabricated by anisotropic cooling from the bottom of the vessel at $-20^{\circ} \mathrm{C}$; (a) cross section parallel to the cooling direction and (b) cross section perpendicular to the cooling direction, entry 10 , porosity $72 \%\left(\mathrm{Al}_{2} \mathrm{O}_{3}\right.$ concent $20 \mathrm{vol} \%$, polymer concent 5 mass $\left.\%\right)$.

anisotropic cooling at $-20^{\circ} \mathrm{C}$. The cross sections of perpendicular to the cooling direction were similar to those in Fig. 9 (a). In contrast, in the cross sections parallel to the cooling direction, continuous open pores aligned to the cooling direction were observed.

The results of the pore structure were consistent with the fact that pore structures of sintered bodies were dependent on the ice crystals that were formed from the water in the slurry by freezing process.

\section{Discussion}

In the present gelate-freezing method, ice crystals grew in the polymer during the freezing process. It is established that, micro-sized ice crystals grow inside when water solved polymers are frozen. ${ }^{10)}$ These ice crystals grown in situ can easily be removed by a process of thawing followed by drying. Therefore, pores in the samples were made from such ice crystals. After the successive sintering process, porous sintered bodies were prepared. Therefore, ice growth is important for both pore size and shape in sintered bodies. The porosity and the pore shape in the sintered bodies we prepared were dependent of the water content in the slurry. Alumina particles attached to each other in the polymer solution; therefore, the gelate-freezing method does not need vacuum dehydration in the drying treatment.

After isotropic cooling at $-20^{\circ} \mathrm{C}$, further cooling in liquid nitrogen enhanced ice growth to give larger pore sizes. The
Table 2. Porosity and Pore Size of Sintered Bodies by the GelateFreezing Method ${ }^{7)-9)}$ and Related Methods

\begin{tabular}{|c|c|c|}
\hline Production method & $\begin{array}{c}\text { Porosity } \\
(\%)\end{array}$ & $\begin{array}{c}\text { Mean pore size } \\
(\mu \mathrm{m})\end{array}$ \\
\hline Gelate-freezing method & $30-70$ & $20-200$ \\
\hline Gel-casting method & $30-70$ & $2-4$ \\
\hline Freeze-dry method & $40-60$ & $20-40$ \\
\hline
\end{tabular}

anisotropic cooling as well as the freeze-dry method was effective for oriented porous material. Cooling temperature and direction involving the ice growth also may affect pore size and shape in sintered bodies. Compared with the porosities of entries 8, 9 and 10, cooling temperature and direction have small affect on the porosity of samples.

The present method is considered to be a gel-casting method combined with a freeze-dry method. For comparison, the characteristic features of porous materials fabricated by the present method and by conventional methods are listed in Table 2.4)-9) The pore size fabricated by the present method is controllable and is larger than that fabricated by the gel-casting method, while the porosities of samples are comparable In the gel-casting method, it is known that porous ceramics with dense structures are fabricated by using fine ceramics powders. Desired features of porous sintered alumina, such as high porosity, continuous open pores, dense structure, and a wide range of pore sizes were achieved with our method. The sintered bodies with pores oriented along the cooling direction may also be prepared by the freeze-dry method.

\section{Conclusions}

We developed a new gelate-freezing method for fabrication of porous ceramics. Using the present method, we fabricated porous alumina sintered bodies with high porosity, continuous open pores, dense structure, and a wide range of pore sizes. Pore size and porosity were able to be controlled by the alumina and water content in the slurry, and by the cooling temperature and direction.

\section{References}

1) Almanza, R. J. M., Cateillejos, E. A. H., Acosta, G. F. A. and Flores, V. A., Mater. Design, Vol. 15, pp. 135-140 (1994).

2) Trimm, D. L. and Stanislaus, A., Appl. Catal., Vol. 21, pp. 215-238 (1986).

3) Keizer, K. and Burggraaf, J., J. Memb. Sci., Vol. 39, pp. 285-300 (1988).

4) Fukasawa, T. and Goto, H., Japanese Patent No. 3124274.

5) Fukasawa, T. and Ando, M., J. Am. Ceram. Soc., Vol. 84, pp. 230-232 (2001).

6) Fukasawa, T., Deng, Z. Y. and Ando, M., J. Mater. Sci., Vol. 36, pp. 2523-2527 (2001).

7) Wang, H. T., Liu, X. Q. and Meng, G. Y., Materials Research Bulletin, Vol. 32, pp. 1705-1712 (1997).

8) Gu,, Y., Liu X., Meng, G. and Peng, D., Ceramics International, Vol. 25, pp. 705-709 (1999).

9) Meng, G., Wang, H., Zheng, W. and Liu, X., Mater. Lett., Vol. 45, pp. 224-227 (2000).

10) Laurie, J., Baganall, C. M., Harris, B., Jones, R. W., Cooke, R. G., Russell-Floyd, R. S., Wang, T. H. and Hammett, F. W., J. Non-Cryst. Solids, Vol. 147, pp. 320-325 (1992). 